\title{
In-vitro secretion of progesterone by the corpus luteum of the tammar wallaby, Macropus eugenii
}

\author{
L. A. Hinds, S. M. Evans* and C. H. Tyndale-Biscoe \\ Division of Wildlife Research, CSIRO, P.O. Box 84, Lyneham, A.C.T. 2602, Australia
}

\begin{abstract}
Summary. Luteal tissue collected from tammars 0, 5, 9 and 16 days after removal of pouch young actively produced progesterone in vitro. On Days 5, 9 and 16 luteal progesterone concentration was not significantly different from Day 0 (quiescence). However, the net production of progesterone was significantly higher on Day $5(P<$ 0.05 ) than at any other stage, and we suggest that the corpus luteum is the main source of the rise in progesterone in the peripheral circulation at Days 5-8 of the delayed or non-delayed cycle.

Addition of ovine prolactin to corpora lutea incubated on Day 5 after removal of pouch young had no effect on luteal progesterone concentration or the production of progesterone. We therefore conclude that the tonic inhibition exerted by prolactin on the corpus luteum does not affect the steroidogenic capacity of the luteal tissue but may inhibit luteal cell growth during quiescence.
\end{abstract}

\section{Introduction}

In female tammars the corpus luteum (CL) formed after post-partum oestrus is arrested and tonically inhibited by the pituitary (Hearn, 1974). During lactation this suppression appears to be mediated by secretion of prolactin from the pituitary (Tyndale-Biscoe \& Hawkins, 1977) but reactivation can be induced experimentally by removal of the sucking pouch young (Renfree \& Tyndale-Biscoe, 1973), denervation of the active mammary gland (Renfree, 1979), injection of bromocriptine (Tyndale-Biscoe \& Hinds, 1981) or hypophysectomy (Hearn 1974; Tyndale-Biscoe \& Hawkins, 1977). When reactivation occurs the corpus luteum increases in size from 10 to about $60 \mathrm{mg}$ (Renfree, Green \& Young, 1979) and circulating progesterone rises from $<200$ to about 600 $\mathrm{pg} / \mathrm{ml}$ (Lemon, 1972; Hinds \& Tyndale-Biscoe, 1982a). However, until about Day 15 of the reactivated cycle, luteal progesterone concentration does not alter significantly (Renfree $e t a l$, 1979) and so the change in plasma progesterone must be due to an increasing rate of production by the $\mathrm{CL}$, an increase in its mass or a change in metabolic clearance rate.

The corpus luteum is devoid of receptors for luteinizing hormone (LH) (Stewart \& TyndaleBiscoe, 1982) but abundant specific binding sites for prolactin are present in luteal tissue during quiescence (Sernia \& Tyndale-Biscoe, 1979) and during the delayed or non-delayed cycle (Stewart \& Tyndale-Biscoe, 1982). The presence of these receptors strongly suggests that the inhibitory effect of prolactin is exerted directly on the CL. However, it is unclear whether this effect is mediated by an inhibition of luteal cell growth or by a suppression of the steroidogenic activity of the CL. Some preliminary studies have shown that, although progesterone is secreted by quiescent $\mathrm{CL}$ in vitro, neither the addition of high concentrations of prolactin nor $\mathrm{LH}$ affected progesterone production (Sernia, Hinds \& Tyndale-Biscoe, 1980). The present study was designed to examine in-

* Present address: Royal Hobart Hospital, Hobart, Tasmania 7000, Australia. 
vitro progesterone production by $\mathrm{CL}$ collected at various times after reactivation had been induced by removal of pouch young or injection of bromocriptine and to correlate this with the increasing mass of the CL and the changes in peripheral progesterone levels. In addition the effect of prolactin on the steroidogenic function of $\mathrm{CL}$ after reactivation was examined.

\section{Materials and Methods}

Ovaries were collected from the tammars at laparotomy or autopsy. A blood sample was taken into a heparinized syringe from the caudal vein or the heart for determination of progesterone. The ovaries were examined and the single $\mathrm{CL}$ and non-luteal ovarian tissue separated and placed on ice.

Each CL was weighed and a piece frozen immediately to provide a pre-incubation measure of tissue progesterone concentration. The other piece of tissue was incubated in $1 \mathrm{ml}$ of freshly gassed $\left(95 \% \mathrm{O}_{2} / 5 \% \mathrm{CO}_{2}\right)$ Krebs-Ringer-Bicarbonate buffer ( $\mathrm{pH} 7 \cdot 0,118 \mathrm{~mm}-\mathrm{NaCl}, 47 \mathrm{mM}-\mathrm{KCl}, 0.25 \mathrm{mM}-$ $\mathrm{CaCl}_{2}, 1.2 \mathrm{mM}-\mathrm{KH}_{2} \mathrm{PO}_{4}, 1.2 \mathrm{~mm}-\mathrm{MgSO}_{4} .7 \mathrm{H}_{2} \mathrm{O}, 2.5 \mathrm{~mm}-\mathrm{NaHCO}_{3}$ ) plus $0.2 \%$ glucose, for $4 \mathrm{~h}$ at $35^{\circ} \mathrm{C}$. After incubation the media and tissues were frozen separately at $-15^{\circ} \mathrm{C}$ until assayed for progesterone. Non-luteal tissue was treated in a similar manner.

Ovine prolactin (NIH-P-S12) was obtained from the National Pituitary Agency, Maryland, U.S.A. Bromocriptine (CB154) was donated by Sandoz (Australia) Pty Ltd, Sydney. All other reagents were analytical grade.

\section{Experiment I}

The following tests were undertaken to validate in-vitro procedures for use with the tammar CL.

(1) Aliquants of medium $(100 \mu \mathrm{l})$ were collected at hourly intervals from duplicate incubations of pieces of one quiescent (Day 0) CL to determine whether the release of progesterone into the medium was at a constant rate over the 4-h incubation period. To establish whether the presence of glucose in the incubation medium was essential, one quiescent CL was bisected and each piece incubated separately in medium lacking glucose. For each experiment the progesterone content of the medium, before and after incubation, was determined to demonstrate that only luteal tissue was synthesizing progesterone.

(2) To check that progesterone production by corpora lutea in vitro represented active production and secretion rather than leakage of the steroid from damaged cells in the tissue, CL were obtained from 5 females 16 days after removal of pouch young and incubated as described earlier. By Day 16 each CL weighed more than $40 \mathrm{mg}$ and so could be divided into 3 or 4 pieces. One or 2 pieces were frozen immediately to measure pre-incubation luteal tissue progesterone concentration while the other 2 pieces were incubated. This allowed two independent duplicate determinations to be made of pre- and post-incubation tissue progesterone concentration and of progesterone in the incubation medium.

\section{Experiment $I I$}

This experiment was designed to measure the rate of secretion of progesterone by CL at various stages during the first half of a reactivated cycle. The earlier experiments (Sernia et al., 1980; and Exp. I) indicated that the rate of secretion by and progesterone concentrations of luteal tissue were similar on Days 0 and 16. Therefore, CL were collected on Days 0, 5, 9 and 16 after removal of pouch young and rate of progesterone production and tissue progesterone concentrations were determined as above. 


\section{Experiment III}

Sernia et al. (1980) found that addition of high concentrations of prolactin $(2 \mu \mathrm{g} / \mathrm{ml})$ to quiescent or Day $1 \mathrm{CL}$ in vitro did not affect the production of progesterone. For this experiment the aim was to determine whether the progesterone secretion rate could be altered by lower, physiological, concentrations of prolactin (Hinds \& Tyndale-Biscoe, 1982b) if the CL were already reactivated and actively producing progesterone. In addition non-luteal ovarian tissue was treated in the same way to resolve whether it contributes to plasma progesterone levels at this time. Corpora lutea and non-luteal ovarian tissue collected 5 days after removal of pouch young and simultaneous injection of bromocriptine ( $2 \mathrm{mg} / \mathrm{kg}$ body weight) were incubated with prolactin $(50 \mu \mathrm{g} / \mathrm{ml})$ and progesterone secretion was determined.

\section{Assay of progesterone}

Plasma, tissue and incubation medium concentrations of progesterone were determined by radioimmunoassay as described by Sernia et al. (1980) using antiserum (Lot S230) supplied by Dr R. I. Cox (CSIRO, Sydney). Antibodies were raised in sheep to progesterone-11-hemisuccinateBSA. Cross-reactivity relative to progesterone was $<0.3 \%$ for $17 \alpha$-hydroxyprogesterone, $20 \alpha-$ or $20 \beta$-hydroxy-4 pregnene-3-one, $3 \beta, 17$-dihydroxy-5-pregnene-20-one, $5 \beta$-pregnane- $3 \alpha, 20 \beta$-diol, $5 \beta$ pregnane- $3 \alpha, 20 \alpha$-diol, cortisol and corticosterone. Higher cross-reactivity was present with 11 -

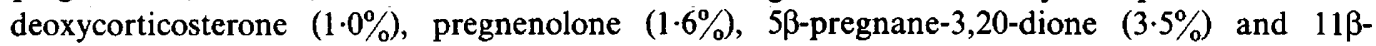
hydroxyprogesterone $(6.7 \%)$. Assay sensitivity, defined as the least measurable amount of progesterone was $25 \mathrm{pg} / \mathrm{ml}$. Intra- and inter-assay coefficients of variation of 9.0 and $13.0 \%$ respectively were determined from repeated measures of a single pool of plasma within the same assay $(n=10)$ and in separate assays $(n=29)$. Before assay tissues were homogenized in $1 \mathrm{ml}$ glassdistilled water using a ground-glass homogenizer. The homogenates and the incubation media were extracted three times with $10 \mathrm{ml}$ freshly redistilled hexane, dried under air, redissolved in $1 \mathrm{ml}$ absolute ethanol and stored at $-15^{\circ} \mathrm{C}$. The ethanol solution was diluted 1:50 and two different duplicate aliquants of between 50 and $200 \mu \mathrm{l}$ were taken for assay. Therefore, each concentration is the mean of 2 results for assays of different volumes.

\section{Calculations}

The net production rate was expressed as $\mathrm{ng}$ steroid $/ \mathrm{mg}$ tissue incubated $/ 4 \mathrm{~h}$. The expression was derived by subtracting the initial concentration of steroid/mg tissue at time 0 from the sum of the steroid concentrations in the incubated tissue and its incubation medium. All tissue weights were expressed as mg wet weight tissue. Results were analysed by the Student's $t$ test or analysis of variance followed by Duncan's multiple range test.

\section{Experiment $I$}

\section{Results}

(1) The progesterone concentrations in aliquants of medium collected at hourly intervals show that the release of progesterone into the medium occurred at a constant and linear rate over the 4-h incubation period. However, if glucose was absent from the medium progesterone release was reduced at $1 \mathrm{~h}$ and total release by $4 \mathrm{~h}$ was one eighth that of CL incubated in medium containing glucose (Text-fig. 1). The concentration of progesterone in medium alone, before and after incubation, was $<25 \mathrm{pg} / \mathrm{ml}$ in all experiments.

(2) Corpora lutea collected at Day 16 actively produced progesterone in vitro. The concentration of progesterone in pre-incubation tissue was not significantly different from that observed after incubation (paired-sample $t$ test, $0.2>P>0.1$ ) indicating that progesterone concentrations in the medium represented a net gain of steroid (Table 1 ). The rate of production was $19.9 \pm 3 \cdot 0$ $\mathrm{ng} / \mathrm{mg} / 4 \mathrm{~h}$. 


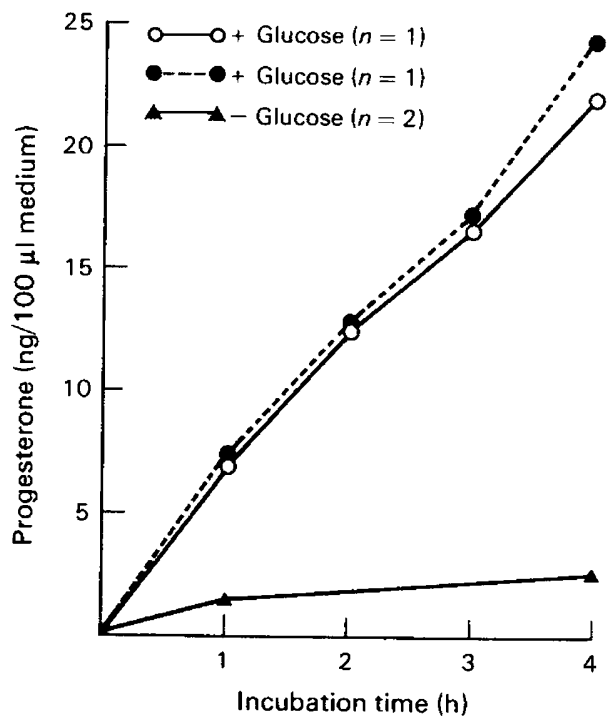

Text-fig. 1. Secretion of progesterone into the medium by pieces of quiescent $C L$ in the presence or absence of glucose in the medium.

Tạble 1. Progesterone production by pieces of CL incubated $0,5,9$ and 16 days after removal of pouch young (RPY)

\begin{tabular}{|c|c|c|c|c|c|c|c|}
\hline \multirow[b]{3}{*}{ Exp. } & \multirow{3}{*}{$\begin{array}{l}\text { Days } \\
\text { after } \\
\text { RPY }\end{array}$} & \multirow{3}{*}{$\begin{array}{l}\text { Wt of } \\
\text { CL } \\
(\mathrm{mg})\end{array}$} & \multirow{2}{*}{\multicolumn{2}{|c|}{$\begin{array}{l}\text { Tissue content } \\
\text { (ng progesterone/mg tissue) }\end{array}$}} & \multicolumn{2}{|c|}{ Progesterone (ng/mg/4 h) } & \multirow{3}{*}{$\begin{array}{l}\text { Plasma } \\
\text { progesterone } \\
(\mathrm{pg} / \mathrm{ml})\end{array}$} \\
\hline & & & & & Secretion & & \\
\hline & & & Pre-incubation & Post-incubation & into medium & production & \\
\hline I & 16 & $53 \cdot 2 \pm 9 \cdot 1(5)$ & $35 \cdot 2 \pm 2 \cdot 2$ & $30 \cdot 3 \pm 2 \cdot 3$ & $18 \cdot 9 \pm 2 \cdot 8$ & $19 \cdot 9 \pm 3 \cdot 0$ & - \\
\hline II & $\begin{array}{r}0 \\
5 \\
9 \\
16\end{array}$ & $\begin{array}{r}7 \cdot 0 \pm 0.2(4) \\
11 \cdot 6 \pm 3 \cdot 8(5) \\
20 \cdot 7 \pm 2 \cdot 6(4) \\
49 \cdot 7 \pm 3 \cdot 1(4)\end{array}$ & $\begin{array}{l}26 \cdot 9 \pm 8 \cdot 6 \\
32 \cdot 1 \pm 4 \cdot 9 \\
19 \cdot 4 \pm 4 \cdot 1 \\
28 \cdot 6 \pm 1 \cdot 6\end{array}$ & $\begin{array}{l}19 \cdot 1 \pm 2 \cdot 3 \\
36 \cdot 0 \pm 5 \cdot 5 \\
15 \cdot 9 \pm 1 \cdot 6 \\
27.9 \pm 3.0\end{array}$ & $\begin{array}{l}31 \cdot 6 \pm 4 \cdot 2 \\
55 \cdot 0 \pm 6 \cdot 7 * \\
13 \cdot 6 \pm 1 \cdot 8 \\
20 \cdot 3 \pm 2 \cdot 7\end{array}$ & $\begin{array}{c}23 \cdot 8 \pm 2 \cdot 7 \\
58 \cdot 8 \pm 8 \cdot 3 \dagger \\
9 \cdot 2 \pm 2 \cdot 5 \\
19 \cdot 6 \pm 6 \cdot 2\end{array}$ & $\begin{array}{l}228 \cdot 3 \pm 25 \cdot 4 \\
440 \cdot 5 \pm 107 \cdot 2 \\
290 \cdot 6 \pm 21 \cdot 7 \\
412.8 \pm 28.9\end{array}$ \\
\hline
\end{tabular}

Values are mean \pm s.e.m. for the no. of CL shown in parentheses.

Values significantly different from Day $0 \mathrm{CL}:{ }^{*} P<0.01,+P<0.05$.

\section{Experiment II}

The increase in the mass of the CL from Day 0 to 16 (Table 1) agrees with the data of Renfree $e t$ al. (1979). As in Exp. I, pre-incubation and post-incubation tissue progesterone concentrations at each stage were not significantly different, while the progesterone concentration in the medium showed a net increase (Table 1).

The pre-incubation tissue progesterone concentrations of $\mathrm{CL}$ collected from females on Days 5 , 9 and 16 were not significantly different from that for the quiescent CL (Day 0$)(P>0.4)$ (Table 1 ). However, the rate of secretion of progesterone into the medium was higher $(P<0.01)$ on Day 5 than on Days 0,9 and 16 (Table 1). This difference was also seen $(P<0.05)$ when the net production of progesterone was derived (Table 1). The high net production in vitro on Day 5 was reflected in higher plasma progesterone values on this day (Table 1), although the differences between Day 5 and Days 0 and 9 are not statistically significant because of the large variation around the mean on Day 5. 


\section{Experiment III}

The progesterone content and production rate of this set of CL collected on Day 5 after simultaneously removing the pouch young and injecting bromocriptine were similar to those collected on the same day in Exp. II (Table 1). The addition of ovine prolactin to the incubation medium had no effect on the tissue progesterone content or the rate of secretion of progesterone into the medium (Table 2). The progesterone content and secretion rate of non-luteal ovarian tissue from the same group of animals were negligible (Table 2).

Table 2. The effect of addition of ovine prolactin (NIH-P-S12, $50 \mathrm{ng} / \mathrm{ml}$ ) on luteal tissue progesterone content and progesterone secretion rate of (a) corpora lutea collected 5 days after removal of pouch young and (b) non-luteal ovarian tissue

\begin{tabular}{|c|c|c|c|c|}
\hline \multirow[b]{2}{*}{ Animal No. } & \multicolumn{2}{|c|}{$\begin{array}{l}\text { Post-incubation tissue content } \\
\text { (ng progesterone/mg tissue) }\end{array}$} & \multicolumn{2}{|c|}{$\begin{array}{l}\text { Progesterone secretion into medium } \\
\qquad(\mathrm{ng} / \mathrm{mg} / 4 \mathrm{~h})\end{array}$} \\
\hline & Control & + Prolactin & Control & + Prolactin \\
\hline \multicolumn{5}{|l|}{ (a) Corpora lutea } \\
\hline 1 & $46 \cdot 3$ & $48 \cdot 4$ & 38.9 & $40 \cdot 8$ \\
\hline 2 & $42 \cdot 1$ & $41 \cdot 5$ & $47 \cdot 2$ & $52 \cdot 4$ \\
\hline 3 & $34 \cdot 8$ & $29 \cdot 8$ & $45 \cdot 7$ & 46.8 \\
\hline 4 & 42.5 & $36 \cdot 2$ & $74 \cdot 4$ & $57 \cdot 2$ \\
\hline 5 & $19 \cdot 1$ & $17 \cdot 8$ & $19 \cdot 3$ & $20 \cdot 8$ \\
\hline $\begin{array}{l}\text { Mean } \pm \text { s.e.m. } \\
\quad(n=5)\end{array}$ & $37 \cdot 0 \pm 4 \cdot 8$ & $34 \cdot 7 \pm 5 \cdot 2$ & $45 \cdot 1 \pm 8 \cdot 8$ & $43 \cdot 6 \pm 6 \cdot 4$ \\
\hline \multicolumn{5}{|c|}{ (b) Non-luteal ovarian tissue } \\
\hline $\begin{array}{l}\text { Mean } \pm \text { s.e.m. } \\
\quad(n=18)\end{array}$ & $0.05 \pm 0.01$ & $0.06 \pm 0.02$ & $0.05 \pm 0.01$ & $0.06 \pm 0.02$ \\
\hline
\end{tabular}

\section{Discussion}

These results show that the CL of the tammar can actively produce progesterone in vitro at a steady rate for $4 \mathrm{~h}$ but non-luteal ovarian tissue cannot produce progesterone under these conditions. In these respects the tammar CL resembles those of eutherian mammals such as the hamster (Terranova, Connor \& Greenwald, 1978), rat, rabbit and guinea-pig (Terranova, Saidapur \& Greenwald, 1980), pig (Hunter, 1981) and man (Hunter \& Baker, 1981). Also, like the CL of eutherians the rate of secretion varied at different days of the cycle; the rate of secretion of quiescent $\mathrm{CL}$ was similar to that of the newly formed rabbit CL but was much less than that of the newly formed rat CL (Terranova et al., 1980). The high rate of secretion on Day 5 was similar to that of the 6-day pig CL (Hunter, 1981) and early human CL (Hunter \& Baker, 1981). Conversely, the rates on Day 9 and 16 were higher than the unstimulated rates of the later stages of CL lifespan of either of these species but were comparable to their rates when incubated with hCG. This is particularly interesting as the CL of the tammar did not respond to LH or prolactin in the medium (Sernia et al., 1980), is devoid of LH receptors (Stewart \& Tyndale-Biscoe, 1982) and can function normally after hypophysectomy (unpublished observations).

Since the non-luteal ovarian tissue of the tammar produced negligible amounts of progesterone, as does the rabbit (Terranova et al., 1980), it is highly likely that the CL is the major source of elevated plasma progesterone during the oestrous cycle and pregnancy in this species. There is a marked but transient peak of progesterone on Day 5 or Day 6 after removing the pouch young, which is followed by a return to basal concentrations by Day 9 and then a slow rise to maximum levels by Day 16 (Hinds \& Tyndale-Biscoe, 1982a). As previously reported by Renfree et al. (1979), 
and confirmed in this study, the concentration of progesterone in luteal tissue remains unchanged between quiescence (Day 0 ) and Day 16 , so that the changes observed in plasma progesterone must arise from changes in total progesterone production by the CL or changes in metabolic clearance of progesterone. The significant increase in production rate in vitro on Day 5 occurred before the $\mathrm{CL}$ had begun to enlarge and so, if the secretion rate in vivo is similarly elevated, this alone would be sufficient to account for the peak in plasma progesterone on Day 5 or 6 . Because the peak occurs on only 1 day in any individual animal the variance around the mean in the present experiments was high and not statistically significant. After Day 5 the progesterone production rate in vitro declined and so could not account for the subsequent major rise in plasma progesterone by Day 16. However, by this day the mass of the CL has increased 5- or 6-fold and this would account for the rise without an increased secretion rate.

Not only is the progesterone production rate unusually high on Day 5 but the luteal cells undergo a transient hyperplasia then (Berger, 1970; Renfree \& Tyndale-Biscoe, 1973) before the hypertrophy that is evident by Day 16. Furthermore, it is only during the brief from Day 4 to Day 8 that ablation of the CL severely affects embryo survival (Sharman \& Berger, 1969; Tyndale-Biscoe, 1970, 1979). Therefore, if prolactin exerts its effect by inhibiting steroidogenesis this is the most probable period. The results of Exp. III, which was designed to test this, did not support the hypothesis that prolactin inhibits steroidogenesis, nor did prolactin affect production of progesterone by quiescent or Day 1 CL (Sernia et al., 1980). We conclude that prolactin has no significant role after the CL has reactivated. Since the removal of inhibition appears to be an all-ornone effect the role of prolactin must be to prevent the initiation of CL growth by hyperplasia and hypertrophy and so only indirectly prevent the rise in plasma progesterone. This is a novel function for prolactin in ovarian control but is analogous to its morphogenetic role in mammogenesis. This conclusion, however, leaves uncertain the reason for the high concentration of prolactin-binding sites on luteal cells on Day 16 (Stewart \& Tyndale-Biscoe, 1982) long after the CL has been released from prolactin constraint.

We thank Dr Ron Cox (CSIRO, Sydney) for progesterone antiserum; Sandoz (Australia) for bromocriptine; the National Pituitary Agency for ovine prolactin; Dr Chris Bryant and Dr Peter Janssens for helpful discussions; and Roy Coles and Ray Leckie for technical assistance. S.M.E. was supported by a Lalor Foundation Fellowship.

\section{References}

Berger, P.J. (1970) Reproductive biology of the tammar wallaby, Macropus eugenii. Ph.D. thesis, Tulane University. (Diss. Abstr. Int. 31B, 3760-3761.)

Hearn, J.P. (1974) The pituitary gland and implantation in the tammar wallaby, Macropus eugenii. J. Reprod. Fert. 39, 235-241.

Hinds, L.A. \& Tyndale-Biscoe, C.H. (1982a) Plasma progesterone levels in the pregnant and non-pregnant tammar, Macropus eugenii. J. Endocr. 93, 99-107.

Hinds, L.A. \& Tyndale-Biscoe, C.H. (1982b) Prolactin in the marsupial Macropus eugenii, during the estrous cycle, pregnancy and lactation. Biol. Reprod. 26, 391 398.

Hunter, M.G. (1981) Responsiveness in-vitro of porcine luteal tissue recovered at two stages of the luteal phase. J. Reprod. Fert. 63, 471-476.

Hunter, M.G. \& Baker, T.G. (1981) Effect of hCG, cAMP and FSH on steroidogenesis by human corpora lutea. J. Reprod. Fert. 63, 285-288.

Lemon, M. (1972) Peripheral plasma progesterone during pregnancy and the oestrous cycle in the tammar wallaby, Macropus eugenii. J. Endocr. 55, 63-71.
Renfree, M.B. (1979) Initiation of development of diapausing embryo by mammary denervation during lactation in a marsupial. Nature, Lond. 278, 549-551.

Renfree, M.B. \& Tyndale-Biscoe, C.H. (1973) Intrauterine development after diapause in the marsupial Macropus eugenii. Devl Biol. 32, 28-40.

Renfree, M.B., Green, S.W. \& Young, I.R. (1979) Growth of the corpus luteum and its progesterone content during pregnancy in the tammar wallaby, Macropus eugenii. J. Reprod. Fert. 57, 131-136.

Sernia, C. \& Tyndale-Biscoe, C.H. (1979) Prolactin receptors in the mammary gland, corpus luteum and other tissues of the tammar wallaby, Macropus eugenii. J. Endocr. 83, 79-89.

Sernia, C., Hinds, L. \& Tyndale-Biscoe, C.H. (1980) Progesterone metabolism during embryonic diapause in the tammar wallaby, Macropus eugenii. J. Reprod. Fert. 60, 139-147.

Sharman, G.B. \& Berger, P.J. (1969) Embryonic diapause in marsupials. Adv. Reprod. Physiol. 4, 211-

Do 240 aded from Bioscientifica.com at 04/26/2023 10:08:47AM 
Stewart, F.S. \& Tyndale-Biscoe, C.H. (1982) Prolactin and luteinizing hormone receptors in marsupial corpora lutea: relationship to control of luteal function. J. Endocr. 92, 63-72.

Terranova, P.F., Connor, J.S. \& Greenwald, G.S. (1978) In-vitro steroidogenesis in corpora lutea and nonluteal ovarian tissues of the cyclic hamster. Biol. Reprod. 19, 249-255.

Terranova, P.F., Saidapur, S.K. \& Greenwald, G.S. (1980) In vitro steroidogenesis of newly formed corpora lutea and the non-luteal ovary in the rat, rabbit, hamster and guinea-pig. J. Endocr. 84, 101-108.

Tyndale-Biscoe, C.H. (1970) Resumption of development by quiescent blastocysts transferred to primed, ovariectomized recipients in the marsupial, Macropus eugenii. J. Reprod. Fert. 23, 25-32.
Tyndale-Biscoe, C.H. (1979) Hormonal control of embryonic diapause and reactivation in the tammar wallaby. In Maternal Recognition of Pregnancy (Ciba Fdn Symp. 64, new series), pp. 173-190. Excerpta Medica, Amsterdam.

Tyndale-Biscoe, C.H. \& Hawkins, J. (1977) The corpora lutea of marsupials: aspects of function and control. In Reproduction and Evolution, pp. 245-252. Eds J. H. Calaby \& C. H. Tyndale-Biscoe. Aust. Acad. Sci., Canberra.

Tyndale-Biscoe, C.H. \& Hinds, L. (1981) Hormonal control of the corpus luteum and embryonic diapause in macropodid marsupials. J. Reprod. Fert., Suppl. 29, 111-117.

Received 29 March 1982 